\title{
Frequency and Effect of the Bovine Acyl-CoA:Diacylglycerol Acyltransferase 1 (DGAT1) K232A Polymorphism in Swedish Dairy Cattle
}

\author{
J. Näslund, ${ }^{1}$ W. F. Fikse, G. R. Pielberg, and A. Lundén \\ Department of Animal Breeding and Genetics, Swedish University of Agricultural Sciences, Box 7023, SE-750 07 Uppsala, Sweden
}

\begin{abstract}
Acyl-CoA:diacylglycerol acyltransferase 1 (DGAT1) is a key enzyme in triacylglycerol synthesis in the mammary gland, and the corresponding gene has emerged as a strong candidate for the variation in milk fat percentage. In this study, the allele frequencies and effects of the DGAT1 K232A variants in the Swedish dairy breeds Swedish Red and Swedish Holstein were investigated. A total of 239 cows, 143 of the Swedish Red breed and 96 of the Swedish Holstein breed, in the experimental herd at the Swedish University of Agricultural Sciences were genotyped for the DGAT1 polymorphism. The Swedish Red cows in the herd belonged to 1 of 2 selection lines with high or low milk fat percentage, respectively, but with similar high total milk energy production. The frequency of the $\mathrm{K}$ variant was found to be significantly greater in the high-fat line than in the low-fat line. The average frequency of the $\mathrm{K}$ variant in the 2 lines of the Swedish Red cows was 0.09 compared with 0.12 among the Swedish Holstein cows. Mixed model analysis was used to estimate the effect of the DGAT1 K232A polymorphism based on 16,866 test-day records for milk production traits. In accordance with previous studies, the most pronounced effects were found for fat and protein percentages and milk yield; and the $K$ variant was associated with an increase in milk fat and protein percentages but less milk yield compared with the A variant. Less pronounced effects were found for yields of fat and protein for which the $\mathrm{K}$ variant was associated with greater fat yield but less protein yield.
\end{abstract}

Key words: DGAT1, genetic polymorphism, cattle, milk fat

\section{INTRODUCTION}

Since 1985, there has been a continuous decrease in fat content in milk from Swedish dairy cows from the

Received May 2, 2007.

Accepted January 7, 2008.

${ }^{1}$ Corresponding author: Jessica.naslund@hgen.slu.se
2 major breeds, Swedish Red (SRB) and Swedish Holstein (SLB) (Lindhé and Philipsson, 2001). Fat content and composition are important from both a consumer perspective and for the dairy industry because they affect processing of milk into cheese and fermented products. Economically, fat is the second most important component in cow's milk, after protein; and the current breeding objective aims to counteract a further decrease in fat content.

Milk fat contains approximately $98 \%$ triglycerides. Characteristic of milk fat from ruminants is the occurrence of short-chain fatty acids comprising 4 to 6 carbon atoms. When triglycerides are synthesized, fatty acids are first attached to positions sn-1 and sn-2 (according to the stereospecific numbering) on the glycerol molecule under the catalyzing effects of enzymes. When a fatty acid is attached to the third position, the enzyme acyl-CoA:diacylglycerol acyltransferase 1 (DGAT1) acts as a catalyst. It is interesting to note that it is only in this position that we find the shortchain fatty acids with 4 to 6 carbon atoms (Marshall and Knudsen, 1977).

A bovine QTL affecting milk yield and composition was reported to be located on bovine chromosome 14 near the centromeric end (Coppieters et al., 1998; Heyen et al., 1999; Looft et al., 2001). Through fine mapping of the QTL region (Riquet et al., 1999; Farnir et al., 2002), the DGAT1 gene emerged as a strong candidate for the QTL effect. The gene encoding the DGAT enzyme had previously been identified in studies of mice (Cases et al., 1998). The A-A to G-C dinucleotide substitution in exon VIII of DGAT1, which gives rise to an amino acid substitution from lysine (K) to alanine (A), was postulated to be the causative mutation (Grisart et al., 2002; Winter et al., 2002). The allele frequency and the effect of the K232A polymorphism have been characterized in dairy cattle populations in New Zealand (Grisart et al., 2002; Spelman et al., 2002), Israel (Weller et al., 2003), the Netherlands (Grisart et al., 2002), Germany (Thaller et al., 2003; Sanders et al., 2006), Poland (Pareek et al., 2005; Strzalkowska et al., 2005), and France (Gautier et al., 2007). The effect of the amino acid substitution is an 
increase in milk and protein yield, and a decrease in fat yield and fat and protein percentage. In a gene expression study it was shown that the lysine variant had a greater enzyme activity level $\left(\mathrm{V}_{\max }\right)$ compared with the alanine variant (Grisart et al., 2004).

The existence of multiple alleles at the DGAT1 locus or a second linked QTL was suggested by Bennewitz et al. (2004), and soon after a variable number of tandem repeats (VNTR) polymorphism was identified in the promoter region of the DGAT1 gene that was associated with variation in milk fat percentage (Kühn et al., 2004). The effect was not as marked as the DGAT1 K232A effect, and in a study in French dairy cattle, the VNTR explained only a small fraction of the QTL variance (Gautier et al., 2007). Moreover, a polymorphism in the gene coding for the enzyme CYP11B1 showed association with milk production and functional traits in German Holstein cattle (Kaupe et al., 2007). However, when accounting for the effects of the DGAT1 K232A and CYP11B1 V30A polymorphisms simultaneously in the statistical analysis, the latter contributed only marginally to the genetic variation in the analyzed milk production traits, compared with the DGAT1 K232A polymorphism alone.

The dairy herd at the Swedish University of Agricultural Sciences includes cows of the SRB and the SLB breeds. The SRB cows belong to 1 of 2 selection lines producing milk with a high or low percentage of milk fat at equal levels of milk energy content, such that cows from both lines have similar nutritional requirements. This material offers an interesting opportunity to explore the biology and genetics behind variation in milk composition and especially fat content. The SLB breed of today is a Swedish counterpart to the various Holstein populations in Europe and North America, and as such, functions as a reference when comparing results between studies. The aims of the present study were to investigate how different breeding strategies affect the allele frequencies at the K232A polymorphism and to estimate the effect of the $D G A T 1 \mathrm{~K} 232 \mathrm{~A}$ in the 2 major Swedish dairy breeds.

\section{MATERIALS AND METHODS}

\section{Breeds and Experimental Structure}

The experimental herd at the University of Agricultural Sciences in Sweden consists of dairy cows of the SRB and the SLB breeds. In 1985, 2 SRB selection lines were created with the aim of developing groups of cows with equal total milk energy production but with high or low milk fat concentration, respectively. The selection of sires for the 2 lines was for high genetic merit for kilograms of $4 \% \mathrm{FCM}$ in combination with either high or low breeding value for fat percentage.
No selection was practiced on the cows. A total of 239 cows in the experimental herd were included in the present study, 96 belonging to the SLB breed and 143 to the SRB breed, of which 78 were selected toward low fat $(\mathbf{S R B} / \mathbf{L F})$ percentage in milk and 65 selected toward high fat (SRB/HF) percentage. Cows of the SLB breed were included in the study to compare effects of the DGAT1 K232A polymorphism between the 2 major dairy breeds in Sweden, at the same time as being a reference when comparing results between studies including Holstein populations of similar (i.e., European and North American) origin. All animals in the study were genotyped for the DGAT1 K232A polymorphism. A total of 77 sires were included in the pedigree, which also included information on dam, maternal grand sire, and paternal grand sire. The total number of individuals in the pedigree was 539 .

\section{Phenotypic Data}

Data comprised 16,866 test-day records from 462 lactations ( 1 to 3 ) of the 239 cows. Milk samples were collected weekly from April 1990 through December 2003. Milk samples were treated with bronopol (Boots Microcheck, Nottingham, UK) immediately after milking, and samples of fresh milk were analyzed for SCC by flow cytometry (Fossomatic 5200, A/S Foss Electric, Hillerød, Denmark). Infrared technique was used to determine the concentrations of fat, protein, and lactose (MilkoScan 93; A/S Foss Electric). Milk data included milk yield, milk yield expressed as kilograms of ECM, concentration and yield of fat and protein, and SCC transformed to the natural logarithm scale (lnSCC). Observations with an SCC $>300,000$ cells $/ \mathrm{mL}$ were not included in the statistical analysis to avoid milk with characteristics of mastitis. Lactation number, lactation week, and season and year of milk sampling were registered for each individual milk sample. Only registrations from the first $305 \mathrm{~d}$ in lactation were used. The mean values and standard deviations for the analyzed milk traits for each parity are in Table 1 .

\section{Genotyping Data}

The DNA from the 239 cows was extracted from blood according to a standard protocol (Higuchi, 1992). The following primers were used for the amplification of a 182-bp PCR fragment containing the DGAT1 K232A mutation: F: 5'-AAG GCC AAG GCT GGT GAG$3^{\prime}$ and R: Biotin-5'-AGG TCA GGT TGT CGG GGT AG-3'.

Polymerase chain reaction amplification was carried out on a PTC-200 DNA Engine (MJ Research, Wal- 
Table 1. Numbers of observations, mean, and SD of test-day yield and composition of milk from 239 cows of the Swedish Holstein breed (SLB) and 2 selection lines ${ }^{1}$ of the Swedish Red breed (SRB/HF and SRB/ LF) by parity

\begin{tabular}{|c|c|c|c|c|c|c|c|c|c|c|}
\hline \multirow[b]{2}{*}{ Trait } & \multirow[b]{2}{*}{ Parity } & \multicolumn{3}{|c|}{ SLB } & \multicolumn{3}{|c|}{$\mathrm{SRB} / \mathrm{HF}$} & \multicolumn{3}{|c|}{$\mathrm{SRB} / \mathrm{LF}$} \\
\hline & & $\mathrm{n}$ & Mean & SD & $\mathrm{n}$ & Mean & SD & $\mathrm{n}$ & Mean & SD \\
\hline \multirow[t]{3}{*}{ Fat content $(\%)$} & 1 & 3,788 & 3.90 & 0.71 & 2,782 & 4.84 & 0.63 & 3,172 & 4.16 & 0.57 \\
\hline & 2 & 1,800 & 3.79 & 0.82 & 1,394 & 4.78 & 0.72 & 1,672 & 4.02 & 0.62 \\
\hline & 3 & 695 & 3.87 & 0.76 & 589 & 4.76 & 0.74 & 975 & 4.10 & 0.68 \\
\hline \multirow[t]{3}{*}{ Protein content $(\%)$} & 1 & 3,788 & 3.34 & 0.34 & 2,782 & 3.62 & 0.37 & 3,172 & 3.36 & 0.34 \\
\hline & 2 & 1,800 & 3.29 & 0.37 & 1,394 & 3.62 & 0.41 & 1,672 & 3.33 & 0.37 \\
\hline & 3 & 695 & 3.24 & 0.36 & 589 & 3.59 & 0.40 & 975 & 3.33 & 0.38 \\
\hline \multirow[t]{3}{*}{ Lactose content (\%) } & 1 & 3,772 & 4.91 & 0.21 & 2,770 & 4.81 & 0.18 & 3,163 & 4.75 & 0.19 \\
\hline & 2 & 1,792 & 4.77 & 0.26 & 1,389 & 4.73 & 0.25 & 1,668 & 4.61 & 0.25 \\
\hline & 3 & 693 & 4.75 & 0.24 & 588 & 4.69 & 0.21 & 973 & 4.63 & 0.24 \\
\hline \multirow[t]{3}{*}{$\ln \mathrm{SCC}$} & 1 & 3,778 & 4.09 & 0.82 & 2,775 & 3.57 & 0.81 & 3,165 & 3.86 & 0.80 \\
\hline & 2 & 1,796 & 4.19 & 0.94 & 1,392 & 4.00 & 0.95 & 1,668 & 4.02 & 0.89 \\
\hline & 3 & 693 & 4.33 & 0.91 & 589 & 4.35 & 0.87 & 966 & 4.21 & 0.89 \\
\hline \multirow[t]{3}{*}{ Milk yield (kg) } & 1 & 3,788 & 29.72 & 6.88 & 2,782 & 24.15 & 5.66 & 3,172 & 25.94 & 6.65 \\
\hline & 2 & 1,800 & 34.15 & 10.09 & 1,394 & 26.25 & 8.92 & 1,672 & 27.85 & 9.75 \\
\hline & 3 & 695 & 34.72 & 10.83 & 589 & 27.67 & 8.69 & 975 & 29.31 & 9.60 \\
\hline \multirow[t]{3}{*}{ Protein yield (kg) } & 1 & 3,788 & 0.98 & 0.19 & 2,782 & 0.86 & 0.18 & 3,172 & 0.86 & 0.19 \\
\hline & 2 & 1,800 & 1.10 & 0.28 & 1,394 & 0.92 & 0.26 & 1,672 & 0.90 & 0.28 \\
\hline & 3 & 695 & 1.10 & 0.28 & 589 & 0.97 & 0.25 & 975 & 0.95 & 0.26 \\
\hline \multirow[t]{3}{*}{ Fat yield (kg) } & 1 & 3,788 & 1.14 & 0.26 & 2,782 & 1.16 & 0.26 & 3,172 & 1.07 & 0.27 \\
\hline & 2 & 1,800 & 1.27 & 0.40 & 1,394 & 1.23 & 0.41 & 1,672 & 1.11 & 0.40 \\
\hline & 3 & 695 & 1.31 & 0.40 & 589 & 1.30 & 0.42 & 975 & 1.18 & 0.39 \\
\hline \multirow[t]{3}{*}{ Lactose yield (kg) } & 1 & 3,772 & 1.46 & 0.36 & 2,770 & 1.17 & 0.29 & 3,163 & 1.24 & 0.34 \\
\hline & 2 & 1,792 & 1.64 & 0.53 & 1,389 & 1.26 & 0.46 & 1,668 & 1.30 & 0.48 \\
\hline & 3 & 693 & 1.66 & 0.54 & 588 & 1.31 & 0.44 & 973 & 1.37 & 0.48 \\
\hline \multirow{3}{*}{ ECM (kg) } & 1 & 3,788 & 31.17 & 6.32 & 2,782 & 28.78 & 6.19 & 3,172 & 28.20 & 6.68 \\
\hline & 2 & 1,800 & 35.14 & 9.74 & 1,394 & 30.86 & 9.77 & 1,672 & 29.62 & 9.94 \\
\hline & 3 & 695 & 35.83 & 10.07 & 589 & 32.51 & 9.60 & 975 & 31.42 & 9.67 \\
\hline
\end{tabular}

${ }^{1}$ Cows from selection lines for high (HF) or low (LF) fat percentage, respectively, but with similar total milk energy production.

tham, MA) in a $25-\mu \mathrm{L}$ reaction volume using the AmpliTaq Gold (Applied Biosystems, Foster City, CA) PCR kit. The reactions were performed with the addition of betaine (Sigma, St. Louis, MO) to improve the PCR reaction. To distinguish between the 2 variants a single PCR was performed in which part of exon 8 was amplified.

The samples were analyzed by using the pyrosequencing method (Ronaghi et al., 1998). The biotinylated PCR product $(20 \mu \mathrm{L})$ was immobilized onto streptavidin-coated paramagnetic beads (Dynal AS, Oslo, Norway) using binding buffer ( $5 \mathrm{~m} M$ Tris-HCl, $1 M \mathrm{NaCl}, 0.5 \mathrm{~m} M$ EDTA, 0.05\% Tween 20, pH 7.6) in a total volume of $80 \mu \mathrm{L}$ during a 10 -min incubation on a vortex mixer (Vortex Genie 2, Scientific Industries, Bohemia, NY). Biotinylated single-stranded DNA was obtained by washing the immobilized PCR product in $0.2 \mathrm{M} \mathrm{NaOH}$ and washing the beads in washing buffer (10 $\mathrm{m} M$ Tris-acetate, $\mathrm{pH}$ 7.6). A total of 15 pmol of detection primer, designed with its $3^{\prime}$ end immediately upstream of the polymorphic site $5^{\prime}$ GCT CGT AGC TTT GGC AGG TA-3', was allowed to hybridize onto single-stranded DNA in $40 \mu \mathrm{L}$ of annealing buffer (20 $\mathrm{m} M$ Tris-acetate, $2 \mathrm{mM} \mathrm{MgAc}$,
$\mathrm{pH}$ 7.6) at $80^{\circ} \mathrm{C}$ for 2 min with subsequent cooling to room temperature. Pyrosequencing was carried out on the PSQ96 Pyrosequencer instrument using the PSQ96 SNP Reagent kit (Biotage AB, Uppsala, Sweden) containing dATP $\alpha \mathrm{S}$, dCTP, dGTP, dTTP, enzyme mixture (DNA polymerase, ATP sulfurylase, luciferase, and apyrase), and substrate mixture (adenosine 5 '-phospho-sulfate and luciferin).

\section{Statistical Analysis}

Data were analyzed with the following model:

$$
\begin{gathered}
y_{i j k l m n o}=\mu+f(\text { gtp })_{i j}+\text { group }_{j}+y s_{k}+\text { parity }_{l} \\
+b_{m 1} w i m+b_{m 2} w_{i m}^{2}+b_{m 3} \ln \left(\text { wim }^{-1}\right) \\
+b_{m 4}\left[\ln \left(w_{i m}^{-1}\right)\right]^{2}+P_{j n}+A_{j n}+e_{i j k l m n o}
\end{gathered}
$$

where $\mathrm{y}_{\mathrm{ijk} \text { lmno }}=$ test-day record; $\mu=$ the overall mean; $y s_{k}=$ the fixed effect of year-season of testing $(\mathrm{k}=1$, $2 \ldots 50)$ group $_{j}=$ the fixed effect of group, $(\mathrm{j}=\mathrm{SLB}$, $\mathrm{SRB} / \mathrm{HF}, \mathrm{SRB} / \mathrm{HF}) ;$ parity $_{l}=$ the fixed effect of parity number, $(l=1,2,3)$; wim = week in milk; $b_{\mathrm{m} 1} \ldots b_{\mathrm{m} 4}=$ the regression coefficients associated with the fixed 
lactation function $(\mathrm{m}=1,2+) ; P_{j n}=$ random environmental effect of cow $\mathrm{n} ; A_{j n}=$ random additive genetic effect of polygenic background for cow $\mathrm{n}$, and $e_{i j k l m n o}=$ the random residual effect.

Separate lactation curves (Ali and Schaeffer, 1987) were fitted for all parities. The shape of the lactation curve was the same for lactations 2 and 3 ; that is, only the level (intercept) of the lactation curve was different for lactations 2 and 3 . Using a parametric curve has several advantages compared with the modeling of subclasses; there are fewer parameters to be estimated, one overcomes the arbitrary definition of the classes, and the model takes into account that the residual variance changes continuously over time (Jaffrezic et al., 2000).

The model included a relationship matrix whereby the additive polygenetic background is accounted for to avoid bias in the estimates of DGAT1 K232A gene effects. Parity and week in milk (wim) were used as repeated measures variables, where parity identifies the multivariate factor and wim the levels of time according to the unstructured and first-order autoregressive structure, denoted UN@AR(1), for multivariate repeated measures. The parameters for the random effects were estimated from the data.

Three different alternatives for $f(g t p)$ were considered in model 1:

$$
\text { 1: } f(g t p)=\left(a+a_{j}\right) x_{1}+\left(d+d_{j}\right) x_{2}
$$

where $\mathrm{x}_{1}=$ the number of copies $(0,1$, or 2$)$ of the $\mathrm{K}$ variant of the DGAT1 gene for the cow $\mathrm{n}$; $\mathrm{a}=$ the additive effect; $\mathrm{x}_{2}=$ indicator variable equal to 1 for the AK genotype and 0 otherwise; and $\mathrm{d}=$ the dominance effect;

$$
\text { 2: } f(\text { gtp })=(\text { group } \times \text { genotype })_{i j}
$$

where genotype $_{\mathrm{i}}=$ the fixed effect of DGAT1 K232A genotype ( $i=\mathrm{AA}, \mathrm{AK}$, or $\mathrm{KK})$; and

$$
\text { 3: } f(g t p)=\left(\alpha+\alpha_{j}\right) x_{1}
$$

where $\alpha=$ the average allele substitution effect (Falconer and Mackay, 1996).

Data were analyzed with the MIXED procedure of the SAS system (SAS Institute, 2006), and traits were analyzed separately. The significance of fixed effects was tested using the $F$-value computed by the MIXED procedure and the containment method for computing the denominator degrees of freedom.

Differences in allele frequencies between the groups were tested using Fisher's exact test.

\section{RESULTS}

\section{Genotype and Allele Frequencies}

Within the SRB/HF cows, the $\mathrm{K}$ variant occurred at a greater frequency $(0.18 ; P<0.0001)$ than in the group of SRB/LF cows (0.01). The $K$ variant and the KK genotype were somewhat more frequent among the SLB cows compared with the pooled average over SRB/ $\mathrm{HF}$ and SRB/LF lines, although this breed difference was not significant. In total there were only 4 cows that were homozygous for the $\mathrm{K}$ variant, 3 of which were of the SLB breed and 1 was in the SRB/HF group (Table 2).

\section{Effect of Selection for Fat Percentage}

The selection lines differed for all traits analyzed $(P$ $<0.05$ ) except kilograms of protein and ECM. The most pronounced difference between the selection lines was in fat percentage, which was 0.59 percentage units lower in the SRB/LF line compared with the SRB/HF line. Protein and lactose concentrations were also lower in the SRB/LF line $(P<0.05)$, whereas milk yield was greater (Table 3 ). The ECM yield was not significantly different between the lines, despite the clear difference in fat concentration, which indicates that the objective of maintaining a high and equal total milk energy production in the 2 lines has been successfully accomplished over time.

The SLB cows produced milk with lower fat and protein percentages than the cows from either of the 2 SRB selection lines, whereas the yields of milk, ECM, and protein, and lactose concentration were greater in the SLB cows (Table 3). The SRB/LF line differed from the other 2 groups by having lower milk fat yield.

\section{Effect of the DGAT1 K232A Polymorphism}

The additive effect of $D G A T 1$ was highly significant for fat concentration in both the SLB and SRB/HF groups. According to the genotypic values in Table 4 , the increase in fat percentage was 0.52 and 0.51 , respectively, for each copy of the $\mathrm{K}$ variant. The genotypic value of the KK genotype was also positive for fat yield and protein concentration in the SLB group, whereas it was not significantly associated with protein yield in any of the groups. There was no significant dominance effect observed for any of the traits. With regard to yield and concentration of lactose and SCC, there were no effects of the DGAT1 polymorphism (data not shown). Imprecise estimates of the additive and dominance effects of DGAT1 were obtained within the SRB/LF line because of the lack of SRB/LF cows 
Table 2. Allele and genotype frequencies of the acyl-CoA:diacylglycerol acyltransferase 1 (DGAT1) K232A polymorphism in the Swedish Holstein breed (SLB) and 2 selection lines of the Swedish Red breed (SRB)

\begin{tabular}{lcccccr}
\hline & & \multicolumn{3}{c}{ Genotype } & & \multicolumn{2}{c}{ Allele } \\
\cline { 3 - 5 } Group $^{1}$ & Cows, $n$ & AA & AK & KK & A & K \\
\hline SRB/HF $^{2}$ & 65 & 0.66 & 0.32 & 0.02 & 0.82 & 0.18 \\
SRB/LF $^{2}$ & 78 & 0.97 & 0.03 & 0 & 0.99 & 0.01 \\
SRB/total & 146 & 0.83 & 0.16 & 0.01 & 0.91 & 0.09 \\
SLB & 96 & 0.76 & 0.20 & 0.03 & 0.86 & 0.14 \\
\hline
\end{tabular}

${ }^{1}$ Group contains information on breed and selection line.

${ }^{2}$ Cows from selection lines for high (HF) or low (LF) fat percentage, respectively, but with similar total milk energy production.

${ }^{3}$ The pooled average of the SRB/HF and SRB/LF lines plus 3 additional cows not included in the selection study.

with the KK genotype and the low number of AK heterozygotes.

Significant differences between the DGAT1 genotypes $\mathrm{AA}$ and $\mathrm{AK}$ were obtained for fat percentage in the SRB/HF group and in the SLB breed, and also between AK and KK genotypes in the SLB breed. Both contrasts regarding protein concentration were significant in the SLB group, whereas for the SRB/HF group only the difference between the AA and AK genotypes was significant. Furthermore, significant contrasts between the AA and AK genotypes for fat yield were obtained in the SRB/HF and SLB groups of cows. For milk and protein yield there were no differences observed between the 3 DGAT 1 genotypes.

The allele substitution effect of changing an A allele for a $\mathrm{K}$ allele was in accordance with the estimated allele effects based on genotypic values. However, the standard errors of the estimates were lower, resulting in significant allele substitution effects for fat yield and protein yield in the $\mathrm{SRB} / \mathrm{HF}$ group of cows.

Table 3. Differences in test-day milk composition and yield between the Swedish Holstein breed (SLB) and 2 selection lines ${ }^{1}$ of the Swedish Red breed (SRB/HF and SRB/LF)

\begin{tabular}{lccr}
\hline & \multicolumn{3}{c}{ Group $^{2}$} \\
\cline { 2 - 4 } Trait & SRB/HF & SRB/LF & \multicolumn{1}{c}{ SLB } \\
\hline Fat content (\%) & $0^{\mathrm{a}}$ & $-0.59 \pm 0.07^{\mathrm{b}}$ & $-0.89 \pm 0.06^{\mathrm{c}}$ \\
Fat yield (kg) & $0^{\mathrm{a}}$ & $-0.09 \pm 0.03^{\mathrm{b}}$ & $0.01 \pm 0.03^{\mathrm{a}}$ \\
Protein content (\%) & $0^{\mathrm{a}}$ & $-0.20 \pm 0.03^{\mathrm{b}}$ & $-0.26 \pm 0.03^{\mathrm{c}}$ \\
Protein yield (kg) & $0^{\mathrm{a}}$ & $-0.00 \pm 0.02^{\mathrm{a}}$ & $0.14 \pm 0.02^{\mathrm{b}}$ \\
Milk yield (kg) & $0^{\mathrm{a}}$ & $1.47 \pm 0.69^{\mathrm{b}}$ & $6.30 \pm 0.66^{\mathrm{c}}$ \\
ECM (kg) & $0^{\mathrm{a}}$ & $0.62 \pm 0.66^{\mathrm{a}}$ & $3.21 \pm 0.63^{\mathrm{b}}$ \\
Lactose content (\%) & $0^{\mathrm{a}}$ & $-0.06 \pm 0.02^{\mathrm{b}}$ & $0.09 \pm 0.02^{\mathrm{c}}$ \\
\hline
\end{tabular}

${ }^{\mathrm{a}-c}$ Values within a row with different superscripts differ $(P<0.05)$.

${ }^{1}$ Cows from selection lines for high (HF) or low (LF) fat percentage, respectively, but with similar total milk energy production.

${ }^{2}$ Group contains information for breed and selection line within SRB breed. Group estimates are expressed relative to the SRB/HF group.

\section{DISCUSSION}

\section{Allele Frequencies}

The consequences of applying different selection strategies were illustrated in this study in which selection for fat concentration in SRB cows has resulted in a concomitant change in allele frequencies at the DGAT1 K232A mutation. Selecting for greater fat concentration in milk seemed to lead to indirect selection for the $\mathrm{K}$ variant.

In Sweden the milk price to the farmer has, for decades, favored milk volume rather than milk components, giving the DGAT1 A variant a selective advantage. This might be a reason for the high frequency of this variant in the present material, in which the frequency of the A variant in the SLB breed (0.86) was considerably higher than in other Holstein populations (Grisart et al., 2002; Spelman et al., 2002; Thaller et al., 2003; Weller et al., 2003; Kaupe et al., 2004) in which selection targeted fat and protein concentrations. Although the A allele also is clearly predominant among the SRB cows in this study, the frequency of the $\mathrm{K}$ variant in the 2 selection lines was somewhat higher than observed in most of the previous studies on Red dairy breeds (Winter et al., 2002; Thaller et al., 2003; Kaupe et al., 2004). This could be a result of the reinforced selection on composition traits. In New Zealand, both Ayrshire and Holstein-Friesian cows carry a relatively high frequency of the $\mathrm{K}$ variant ( 0.60 and 0.22 , respectively), possibly because of the strong selection for high DM content of milk (Spelman et al., 2002). Because the SRB breed has a reputation of producing milk with relatively high fat and protein percentages and the SLB breed is known to have a high milk yield, the 2 lines of SRB cows were expected to have a greater frequency of the $\mathrm{K}$ variant than the SLB cows. However, there was no difference in allele frequencies between the breeds in this limited material. 
Table 4. Effect of the acyl-CoA:diacylglycerol acyltransferase 1 (DGAT1) K232A polymorphism on milk composition and milk yield in the Swedish Holstein breed (SLB) and 2 selection lines ${ }^{1}$ of the Swedish Red breed (SRB/HF and SRB/LF)

\begin{tabular}{|c|c|c|c|c|c|}
\hline \multirow[b]{2}{*}{ Item } & \multicolumn{5}{|c|}{ Trait } \\
\hline & $\begin{array}{c}\text { Fat content } \\
(\%)\end{array}$ & $\begin{array}{l}\text { Fat yield } \\
(\mathrm{kg})\end{array}$ & $\begin{array}{c}\text { Protein content } \\
(\%)\end{array}$ & $\begin{array}{l}\text { Protein yield } \\
(\mathrm{kg})\end{array}$ & $\begin{array}{l}\text { Milk yield } \\
(\mathrm{kg})\end{array}$ \\
\hline \multicolumn{6}{|l|}{$a^{2}$} \\
\hline SLB & $0.52 \pm 0.10^{* * *}$ & $0.10 \pm 0.04 *$ & $0.14 \pm 0.05^{* *}$ & $0.01 \pm 0.03$ & $-0.89 \pm 1.05$ \\
\hline $\begin{array}{l}\text { SRB/HF } \\
\mathrm{d}^{3}\end{array}$ & $0.51 \pm 0.17^{* *}$ & $0.10 \pm 0.07$ & $0.11 \pm 0.09$ & $0.02 \pm 0.06$ & $-0.13 \pm 1.84$ \\
\hline SLB & $-0.06 \pm 0.11$ & $0.02 \pm 0.05$ & $0.04 \pm 0.06$ & $0.01 \pm 0.04$ & $0.48 \pm 1.28$ \\
\hline $\begin{array}{r}\mathrm{SRB} / \mathrm{HF} \\
\mathrm{SRB} / \mathrm{HF}^{4}\end{array}$ & $0.12 \pm 0.18$ & $-0.01 \pm 0.08$ & $0.01 \pm 0.10$ & $-0.04 \pm 0.06$ & $-1.23 \pm 1.99$ \\
\hline AA-AK & $0.64 \pm 0.08^{* * *}$ & $0.09 \pm 0.04^{*}$ & $0.11 \pm 0.05^{*}$ & $-0.04 \pm 0.03$ & $-1.36 \pm 0.93$ \\
\hline $\begin{array}{r}\text { AK-KK } \\
\text { SRB/LF }\end{array}$ & $0.39 \pm 0.34$ & $0.10 \pm 0.15$ & $0.10 \pm 0.19$ & $0.14 \pm 0.13$ & $-1.10 \pm 3.73$ \\
\hline $\begin{array}{l}\text { AA-AK } \\
\text { SLB }^{4}\end{array}$ & $0.16 \pm 0.23$ & $-0.08 \pm 0.10$ & $-0.06 \pm 0.12$ & $-0.13 \pm 0.09$ & $-2.51 \pm 2.50$ \\
\hline AA-AK & $0.46 \pm 0.08^{* * *}$ & $0.12 \pm 0.04^{* *}$ & $0.10 \pm 0.05^{*}$ & $0.01 \pm 0.03$ & $-0.41 \pm 0.92$ \\
\hline$\underset{\alpha^{5}}{\mathrm{AK}-\mathrm{KK}}$ & $0.59 \pm 0.19^{* *}$ & $0.09 \pm 0.08$ & $0.18 \pm 0.11^{*}$ & $0.00 \pm 0.07$ & $-1.37 \pm 2.15$ \\
\hline SLB & $0.49 \pm 0.07^{* * *}$ & $0.11 \pm 0.03^{* * * *}$ & $0.12 \pm 0.04^{* *}$ & $0.01 \pm 0.03$ & $-0.61 \pm 0.75$ \\
\hline $\mathrm{SRB} / \mathrm{HF}$ & $0.62 \pm 0.08^{* * *}$ & $0.09 \pm 0.03^{* *}$ & $0.11 \pm 0.04^{* *}$ & $-0.02 \pm 0.06$ & $-1.13 \pm 0.86$ \\
\hline
\end{tabular}

${ }^{1}$ Cows from selection lines for high (HF) or low (LF) fat percentage, respectively, but with similar total milk energy production.

${ }^{2}$ Half of the difference between the genotypic values of the KK and AA genotypes.

${ }^{3}$ Deviation of the AK genotypic value from the midpoint of the AA and KK genotypic values.

${ }^{4}$ Contrasts between homozygote and heterozygote genotypes.

${ }^{5}$ Allele substitution effect of changing A to $\mathrm{K}$.

$* P<0.05 ; * * P<0.01 ; * * * P<0.001$.

\section{Effect of the DGAT1 K232A Polymorphism}

In this study we used a unique data set consisting of a large set of phenotypic records of genotyped daughters. In contrast to using granddaughter designs, this approach enabled estimation of additive and dominance effects. The accuracy of the estimates regarding the effect of the $\mathrm{K}$ allele suffered from the small number of KK homozygous individuals in the material. Apart from this, the estimated effects of the DGAT1 K232A polymorphism in this study were similar to previously published results (Grisart et al., 2002; Spelman et al., 2002; Thaller et al., 2003; Sanders et al., 2006). The allele substitution effects for fat and protein concentration were, however, larger in this study than those reported by Thaller et al. (2003) but were similar to the allele substitution effects in the daughter design by Grisart et al. (2002). The lack of dominance effects were in accordance with previous results (Grisart et al., 2002).

The DGAT1 K232A effect on fat concentration has been reported to differ in magnitude between breeds (Spelman et al., 2002; Thaller et al., 2003; Gautier et al., 2007). However, the estimated allele substitution effect was not significantly different for the SRB/HF compared with the SLB cows, and the genotypic values for fat concentration in this material were similar for the SRB/HF and SLB cows. This contradicts the existence of breed differences regarding the DGAT1 effects in this material. Differences in effects on fat concentration may be because of the interaction with background genes, which might differ between breeds. Although DGAT1 plays a highly significant role in the formation of triglycerides, other genes can be of importance in the various pathways involved in the milk fat synthesis. However, accounting for a random polygenic component in the model and using a known pedigree relationship matrix is expected to reduce the effect of the background genome. Because this study is part of a larger project aiming to identify genetic factors affecting off-flavors in milk we chose not to genotype for the VNTR reported by Kühn et al. (2004), because its effect would be expected to be similar but less pronounced compared with the effect of the $D G A T 1 \mathrm{~K} 232 \mathrm{~A}$ polymorphism. However, if the effect of the DGAT1 K232A polymorphism on occurrence of off-flavors is found to be marginal, genotyping for additional polymorphisms in the chromosomal region around the DGAT1 gene may be performed.

By creating divergent lines for milk fat concentration, the 2 groups of cows are more likely to segregate 
for genes with major effects on the trait, which was indeed shown to be the case with the DGAT1 polymorphism in which the applied selection was reflected in the frequency of DGAT1 K232A variants. A previous study with a limited number of cows from the 2 selection lines indicated that the applied selection has altered not only the fat concentration of the milk, but also fat composition (Agenas et al., 2003). Knowing the function of the DGAT1 enzyme and the special features of bovine milk fatty acid composition, it could be expected that the DGAT1 K232A polymorphism would also have an effect on fat composition. Our initial results from fatty acid analysis of a subsample of the milk samples included in the present study indicate that the DGAT1 genotype AA is associated with an increased proportion of C18:2 (Näslund et al., 2006). Because milk fat composition is known to influence the quality of dairy products, further studies on the effect of DGAT1 are warranted.

\section{ACKNOWLEDGMENTS}

The Swedish Farmers' Foundation for Agricultural Research is acknowledged for financial support. We also thank the staff at Jälla for providing the data for the study.

\section{REFERENCES}

Agenas, S., E. Burstedt, and K. Holtenius. 2003. Effects of feeding intensity during the dry period. 1. Feed intake, body weight, and milk production. J. Dairy Sci. 86:870-882.

Ali, T. E., and L. R. Schaeffer. 1987. Accounting for covariances among test-day milk yields in dairy cows. Can. J. Anim. Sci. 67:637-644.

Bennewitz, J., N. Reinsch, S. Pau, C. Looft, B. Kaupe, C. Weimann, G. Erhardt, G. Thaller, C. Kühn, M. Schwerin, H. Thomsen, F. Reinhardt, R. Reents, and E. Kalm. 2004. The DGAT1 K232A mutation is not solely responsible for the milk production quantitative trait locus on the bovine chromosome 14. J. Dairy Sci. 87:431-442.

Cases, S., S. J. Smith, Y. W. Zheng, H. M. Myers, S. R. Lear, E. Sande, S. Novak, C. Collins, C. B. Welch, A. J. Lusis, S. K. Erickson, and R. V. Farese Jr. 1998. Identification of a gene encoding an acyl CoA:diacylglycerol acyltransferase, a key enzyme in triacylglycerol synthesis. Proc. Natl. Acad. Sci. USA 95:13018-13023.

Coppieters, W., J. Riquet, J. J. Arranz, P. Berzi, N. Cambisano, B. Grisart, L. Karim, F. Marcq, L. Moreau, C. Nezer, P. Simon, P. Vanmanshoven, D. Wagenaar, and M. Georges. 1998. A QTL with major effect on milk yield and composition maps to bovine chromosome 14. Mamm. Genome 9:540-544.

Falconer, D. S., and T. F. C. Mackay. 1996. Introduction to Quantitative Genetics. 4th ed. Longman Scientific and Technical, New York, NY.

Farnir, F., B. Grisart, W. Coppieters, J. Riquet, P. Berzi, N. Cambisano, L. Karim, M. Mni, S. Moisio, P. Simon, D. Wagenaar, J. Vilkki, and M. Georges. 2002. Simultaneous mining of linkage and linkage disequilibrium to fine map quantitative trait loci in outbred half-sib pedigrees: Revisiting the location of a quantitative trait locus with major effect on milk production on bovine chromosome 14. Genetics 161:275-287.
Gautier, M., A. Capitan, S. Fritz, A. Eggen, D. Boichard, and T. Druet. 2007. Characterization of the DGAT1 K232A and variable number of tandem repeat polymorphisms in French dairy cattle. J. Dairy Sci. 90:2980-2988.

Grisart, B., W. Coppieters, F. Farnir, L. Karim, C. Ford, P. Berzi, N. Cambisano, M. Mni, S. Reid, P. Simon, R. Spelman, M. Georges, and R. Snell. 2002. Positional candidate cloning of a QTL in dairy cattle: Identification of a missense mutation in the bovine DGAT1 gene with major effect on milk yield and composition. Genome Res. 12:222-231.

Grisart, B., F. Farnir, L. Karim, N. Cambisano, J. J. Kim, A. Kvasz, M. Mni, P. Simon, J. M. Frere, W. Coppieters, and M. Georges. 2004. Genetic and functional confirmation of the causality of the DGAT1 K232A quantitative trait nucleotide in affecting milk yield and composition. Proc. Natl. Acad. Sci. USA 101:23982403.

Heyen, D. W., J. I. Weller, M. Ron, M. Band, J. E. Beever, E. Feldmesser, Y. Da, G. R. Wiggans, P. M. VanRaden, and H. A. Lewin. 1999. A genome scan for QTL influencing milk production and health traits in dairy cattle. Physiol. Genomics 1:165-175.

Higuchi, R. 1992. Simple and rapid preparation of samples for PCR. Pages 31-38 in PCR Technology: Principles and Applications for DNA Amplification. H. A. Ehrlich, ed. Stockton Press, New York. NY.

Jaffrezic, F., I. M. White, R. Thompson, and W. G. Hill. 2000. A link function approach to model heterogeneity of residual variances over time in lactation curve analyses. J. Dairy Sci. 83:1089-1093.

Kaupe, B., H. Brandt, E. M. Prinzenberg, and G. Erhardt. 2007. Joint analysis of the influence of CYP11B1 and DGAT1 genetic variation on milk production, somatic cell score, conformation, reproduction, and productive lifespan in German Holstein cattle. J. Anim. Sci. 85:11-21.

Kaupe, B., A. Winter, R. Fries, and G. Erhardt. 2004. DGAT1 polymorphism in Bos indicus and Bos taurus cattle breeds. J. Dairy Res. 71:182-187.

Kühn, C., G. Thaller, A. Winter, O. R. P. Bininda-Emonds, B. Kaupe, G. Erhardt, J. Bennewitz, M. Schwerin, and R. Fries. 2004. Evidence for multiple alleles at DGAT1 locus better explains a QTL with major effect on milk fat content in cattle. Genetics 167:1873-1881.

Lindhé, B., and J. Philipsson. 2001. Genetic trends in the two Swedish dairy cattle breeds SRB and SLB in 1985-1999. Publ. No. 138. Swedish Univ. of Agric. Sci., Dept. Anim. Breed. Genet., Uppsala, Sweden.

Looft, C., N. Reinsch, C. Karall-Albrecht, S. Paul, M. Brink, H. Thomsen, G. Brockmann, C. Kuhn, M. Schwerin, and E. Kalm. 2001. A mammary gland EST showing linkage disequilibrium to a milk production QTL on bovine chromosome 14. Mamm. Genome 12:646-650.

Marshall, M. O., and J. Knudsen. 1977. Biosynthesis of triacylglycerols containing short-chain fatty acids in lactating cow mammary gland. Activity of diacylglycerol acyltransferase towards shortchain acyl-CoA esters. Eur. J. Biochem. 81:259-266.

Näslund, J., T. Allmere, J. Pickova, and A. Lundén. 2006. Milk fatty acid composition in two groups of Swedish dairy cattle and its association with DGAT1 polymorphism. Commun. 12-04 in Proc. 8th World Congr. Genet. Appl. Livest. Prod., Belo Horizonte, Brazil.

Pareek, C. S., U. Czarnik, T. Zabolewicz, R. S. Pareek, and K. Walawski. 2005. DGAT1 K232A quantitative trait nucleotide polymorphism in Polish Black-and-White cattle. J. Appl. Genet. $46: 85-87$.

Riquet, J., W. Coppieters, N. Cambisano, J. J. Arranz, P. Berzi, S. K. Davis, B. Grisart, F. Farnir, L. Karim, M. Mni, P. Simon, J. F. Taylor, P. Vanmanshoven, D. Wagenaar, J. E. Womack, and M. Georges. 1999. Fine-mapping of quantitative trait loci by identity by descent in outbred populations: Application to milk production in dairy cattle. Proc. Natl. Acad. Sci. USA 96:9252-9257.

Ronaghi, M., M. Uhlen, and P. Nyren. 1998. A sequencing method based on real-time pyrophosphate. Science 281:363-365.

Sanders, K., J. Bennewitz, N. Reinsch, G. Thaller, E. M. Prinzenberg, C. Kühn, and E. Kalm. 2006. Characterization of the 
DGAT1 mutations and the CSN1S1 promoter in the German Angeln dairy cattle population. J. Dairy Sci. 89:3164-3174.

SAS Institute. 2006. SAS OnlineDoc 9.1.3. SAS Institute Inc., Cary, NC.

Spelman, R. J., C. A. Ford, P. McElhinney, G. C. Gregory, and R. G. Snell. 2002. Characterization of the DGAT1 gene in the New Zealand dairy population. J. Dairy Sci. 85:3514-3517.

Strzalkowska, N., E. Siadkowska, K. Sloniewski, J. Krzyzewski, and L. Zwierzchowski. 2005. Effect of DGAT1 gene polymorphism on milk production traits in Black-and-White (Friesian) cows. Anim. Sci. Pap. Rep. 23:189-197.
Thaller, G., W. Kramer, A. Winter, B. Kaupe, G. Erhardt, and R. Fries. 2003. Effects of DGAT1 variants on milk production traits in German cattle breeds. J. Anim. Sci. 81:1911-1918.

Weller, J. I., M. Golik, E. Seroussi, E. Ezra, and M. Ron. 2003. Population-wide analysis of a QTL affecting milk-fat production in the Israeli Holstein population. J. Dairy Sci. 86:2219-2227.

Winter, A., W. Kramer, F. A. Werner, S. Kollers, S. Kata, G. Durstewitz, J. Buitkamp, J. E. Womack, G. Thaller, and R. Fries. 2002. Association of a lysine-232/alanine polymorphism in a bovine gene encoding acyl-CoA:diacylglycerol acyltransferase (DGAT1) with variation at a quantitative trait locus for milk fat content. Proc. Natl. Acad. Sci. USA 99:9300-9305. 